\title{
PENGARUH GENDER TERHADAP HASIL BELAJAR SISWA KELAS VII SMP DARUL ULUM 5 JOMBANG MATA PELAJARAN IPA MATERI PEMANASAN GLOBAL MENGGUNAKAN MODEL PEMBELAJARAN DISCOVERY LEARNING
}

\author{
Nurul Lathifatul Hakimah \\ S-1 Pendidikan Ilmu Pengetahuan Alam, Fakultas Ilmu Pendidikan, Universitas Hasyim Asy'ari, \\ nurullathifatulhakimah@gmail.com \\ Nur Kuswanti \\ Pendidikan IPA FIP UNHASY \\ nurkuswanti2013@gmail.com \\ Andri Wahyu Wijayadi \\ Pendidikan IPA FIP UNHASY \\ diaandri@gmail.com
}

\begin{abstract}
Abstrak
Penelitian ini bertujuan untuk mengetahui pengaruh gender terhadap hasil belajar siswa kelas VII SMP Darul Ulum 5 Jombang mata pelajaran IPA materi Pemanasan Global menggunakan model pembelajaran Discovery Learning. Penelitian ini menggunakan metode true experimental design. Populasi dalam penelitian ini adalah seluruh siswa kelas VII SMP Darul Ulum 5 Jombang pada semester genap tahun pelajaran 2017/2018. Sampel penelitian ini adalah siswa kelas VII A (putri) dan kelas VII B (putra) SMP Darul Ulum 5 Jombang. Teknik pengumpulan data dilakukan dengan tiga cara yaitu metode tes, observasi dan angket. Instrumen yang digunakan adalah lembar tes (posttest), lembar observasi keterlaksanaan pembelajaran dan angket respon siswa. Hasil uji hioptesis menggunakan independent sample t-test dengan SPSS'25 menunjukkan bahwa posttest kelas putri dan putra diperoleh nilai signifikansi sebesar $0,000<0,05$ yang menunjukkan Ha diterima dan $\mathrm{H}_{0}$ ditolak. Berdasarkan hasil uji-t tersebut terdapat pengaruh gender terhadap hasil belajar siswa kelas VII SMP Darul Ulum 5 Jombang mata pelajaran IPA materi Pemanasan Global menggunakan model pembelajaran Discovery Learning. Hasil observasi keterlaksanaan pembelajaran kelas gender menggunakan model pembelajaran Discovery Learning materi Pemanasan Global kelas VII di SMP Darul Ulum 5 Jombang terlaksana dengan sangat baik, persentase nilai rata-rata keterlaksanaan pembelajaran pertemuan pertama kelas putri 98,5\% dan terlaksana $97 \%$ pada kelas putra, sedangkan persentase pada pertemuan kedua dan ketiga kedua kelas gender sebesar 100\%. Pembelajaran IPA materi Pemanasan Global dengan menggunakan model pembelajaran Discovery Learning respon positif siswa kelas putri sebesar 89,2\% dan 91,4\% oleh kelas putra dengan kriteria sangat baik.
\end{abstract}

Kata Kunci: Gender, Hasil Belajar Siswa, Mata Pelajaran IPA, Discovery Learning.

\begin{abstract}
This study aims to determine the effect of gender on the learning outcomes of class VII students of Darul Ulum 5 Junior High School Jombang on the science subject of Global Warming material using Discovery Learning model. This research uses true experimental design method. The populations in this study were all seventh grade students of Darul Ulum 5 Junior High School Jombang in the second semester of academic year 2017/2018. The samples of this study were students of class VII A (female) and class VII B (male) of Darul Ulum 5 Junior High School Jombang. Techniques of collecting data are carried out in three ways, namely test, observation and questionnaire methods. The instruments used were test sheets (post-test), observation sheets for learning implementation and student response questionnaires. The results of the hypothesis test using independent sample t-test with SPSS'25 showed that the posttest of the female and male classes obtained a significance value for about $0.000<0.05$ which is showed that Ha was accepted and $\mathrm{H} 0$ was rejected. Based on the results of the t-test, there is a gender influence on the learning outcomes of students class VII of Darul Ulum 5 Junior High School Jombang on science subject of Global Warming material using Discovery Learning model. The results of observations of
\end{abstract}


gender class learning using Discovery Learning for Global Warming material in the class VII at the Darul Ulum 5 Junior High School Jombang were carried out very well, the percentage of the average value of the learning achievement in the first meeting of the female class $98.5 \%$ and $97 \%$ in the male class, while the percentage in the second and third meetings of the gender class is $100 \%$. Science learning material on Global Warming by using Discovery Learning model has positive response of female class students by $89.2 \%$ and $91.4 \%$ by male class with very good criteria.

Keywords: Gender, Student Learning Outcomes, Science Subjects, Discovery Learning.

\section{PENDAHULUAN}

IPA merupakan ilmu yang terkonstruksi secara personal dan sosial berlandaskan pendekatan konstruktivisme. Pembelajaran IPA memerlukan kesempatan yang luas bagi peserta didik untuk melakukan inkuiri dan mengonstruksi sains seoptimal mungkin sesuai dengan kapasitas mereka masing-masing dengan memanfaatkan iklim kolaboratif di dalam kelas. Peran guru di sini sangat vital untuk dapat mengelola proses pembelajaran IPA dengan baik. Peran seorang guru dalam melaksanakan strategi pembelajaran IPA yang baik adalah sebagai sumber belajar, fasilitator, pengelola, demonstrator, pembimbing, motivator, evaluator, dan katalisator dalam pembelajaran, serta pengontrol konsep IPA yang dipahami peserta didik (Wisudawati dan Sulistyowati, 2015: 21). Berdasarkan observasi awal, data rekapitulasi angket dan wawancara guru IPA, Bapak Rudi Setyawan di SMP Darul Ulum 5 Jombang, pada tanggal 13 desember 2017, SMP Darul Ulum 5 Jombang adalah sekolah yang berdiri di lingkungan pesantren. Pendidikan sekolah berbasis pesantren menerapkan adanya pemisahan kelas antara siswa laki-laki dan perempuan (adanya kelas gender). Permasalahan yang diperoleh antara lain: 1) Pelaksanaan Pembelajaran IPA lebih sering menggunakan ceramah (teacher centered) dalam kelas siswa laki-laki dan perempuan (gender); 2) Guru IPA lebih menguasai materi fisika; 3) Siswa kurang aktif dan semangat dalam proses pembelajaran; 4) Siswa laki-laki cenderung susah dikondisikan saat proses pembelajaran; 5) Siswa perempuan cenderung diam dan kurang memperhatikan saat proses pembelajaran; dan 6) Materi Pemanasan Global dianggap sulit oleh siswa kelas laki- laki dan perempuan (kelas gender) berdasarkan hasil belajar pada tahun sebelumnya.

SMP Darul Ulum 5 Jombang adalah sekolah berbasis pesantren yang menerapkan adanya pemisahan kelas dalam proses pembelajaran antara siswa laki-laki dan perempuan. Perbedaan antara laki-laki dan perempuan hampir ada di setiap lini kehidupan baik pada pendidikan, sosial, politik, dan sebagainya. Menurut Sulistiana dkk. (2013) orang sering melihat jenis kelamin seseorang sebagai prediktor penting atas kemampuan seseorang. Kesetaraan gender merupakan prioritas dunia dalam mensejahterakan masyarakat, terutama dalam hal pendidikan. Pelaksanaan proses pembelajaran IPA di SMP Darul Ulum 5 Jombang berdasarkan hasil angket guru sudah baik. Guru tidak hanya menerapkan metode pembelajaran ceramah (teacher centered), tetapi juga dikombinasi dengan metode diskusi dan tanya jawab. Guru juga sesekali menerapkan model pembelajaran inovatif yakni model pembelajaran discovery learning. Meskipun demikian, dalam pelaksanaannya model pembelajaran discovery learning selalu didominasi dengan ceramah, sehingga siswa merasa bosan dan kurang semangat dalam pembelajaran. Akibatnya materi pelajaran kurang dapat dimengerti oleh siswa. Dalam penerapan Kurikulum 2013 di SMP Darul Ulum 5 Jombang, semua guru diwajibkan untuk lebih kreatif dalam mengajar, dimana pembelajaran menggunakan metode pembelajaran aktif yakni metode yang membuat siswa menjadi lebih aktif dalam setiap proses pembelajaran. Guru hanya berperan sebagai fasilitator saja (Kurniasih \& Sani, 2016: 9). Sugihartono, dkk. (2007: 37) mengemukakan bahwa hubungan antara gender dengan prestasi dalam dunia 
pendidikan, laki-laki lebih superior dalam kemampuan spasial yang belanjut selama masa sekolah, di bidang ilmu matematika hanya ada sedikit perbedaan di tahun-tahun awal, sedangkan di bidang ilmu sains perbedaaan gender terlihat meningkat, perempuan mengalami kemunduran, sementara prestasi laki-laki meningkat. Di samping itu, anak perempuan pada umumnya mencapai nilai lebih tinggi pada tes prestasi, karena lebih rajin dan tekun, lebih sedikit mengulang kelas dan kurang menimbulkan masalah (Munandar, 2004).

Perbedaan kualitas proses pembelajaran siswa laki-laki dan siswa perempuan berdasarkan kelas gender sangat penting untuk diperhatikan, terutama dalam proses pembelajaran. Guru sebagai fasilitator harus mengenal perbedaan karakteristik siswa. Hal ini penting untuk menentukan model, strategi maupun metode pembelajaran, supaya tujuan pembelajaran dapat tercapai secara maksimal. Hal ini didukung oleh penelitian Zahroh (2012), bahwa gender memiliki pengaruh langsung terhadap prestasi belajar siswa. Adapun penelitian lain yang dilakukan oleh Akromah (2017) dalam skripsinya bahwa model discovery learning berpengaruh signifikan terhadap kemampuan berpikir kritis siswa pada materi Sistem Tata Surya dan Kehidupan di Bumi mata pelajaran IPA kelas VIII di MTs Babussalam Kalibening Mojoangung.

Berdasarkan uraian yang melatarbelakangi penelitian ini maka penulis tertarik untuk melakukan penelitian dengan judul, "Pengaruh Gender Terhadap Hasil Belajar Siswa Kelas VII SMP Darul Ulum 5 Jombang Mata Pelajaran IPA Materi Pemanasan Global Menggunakan Model Pembelajaran Discovery Learning".

\section{METODE}

Penelitian ini menggunakan metode eksperimen jenis true experimental design. Rancangan penelitian ini posttest-only control design. seperti pada Gambar 1.

$$
\begin{array}{lll}
\mathbf{R}_{1} & \mathbf{X} & \mathbf{O}_{1} \\
\mathbf{R}_{2} & \mathbf{X} & \mathbf{O}_{2}
\end{array}
$$

Gambar 1. Rancangan penelitian

Keterangan :

$\mathrm{R}=$ kelas gender siswa laki-laki
$\mathrm{R}_{2}=$ kelas gender siswa perempuan

$\mathrm{X}=$ Perlakuan Model pembelajaran discovery learning

$\mathrm{O}_{1}=$ nilai post-test (setelah diberi perlakuan) siswa laki-laki

$\mathrm{O}_{2}=$ nilai post-test (setelah diberi perlakuan) siswa perempuan

Populasi dalam penelitian ini adalah seluruh siswa kelas VII SMP Darul Ulum 5 Jombang pada semester genap tahun pelajaran 2017/2018. Sampel pada penelitian ini siswa kelas VII A (kelas putri) dan VII B (kelas putra). Teknik pengambilan sampel menggunakan total sampling atau sampling jenuh. Teknik pengumpulan menggunakan metode Tes (soal tes kognitif) dan Nontes (observasi dan angket). Data yang diperoleh berupa keterlaksanaan pembelajaran dihitung menggunakan rumus sebagai berikut:

$K P(\%)=\frac{\text { skor total yang didapat }}{\text { skor maksimal }} \times 100$

Data yang diperoleh kemudian dikategorikan beradasarkan pedoman sebagai berikut:

Tabel 1. Kriteria Keterlaksanaan Pembelajaran

\begin{tabular}{|c|c|c|}
\hline $\begin{array}{c}\text { Keterlaksanaan } \\
\text { Pembelejaran (\%) }\end{array}$ & Kriteria & Simbol \\
\hline $46 \leq \mathrm{KP} \leq 55$ & Sangat Kurang & SK \\
\hline $56 \geq \mathrm{KP} \leq 65$ & Kurang & $\mathrm{K}$ \\
\hline $66 \geq \mathrm{KP} \leq 75$ & Cukup & $\mathrm{C}$ \\
\hline $76 \geq \mathrm{KP} \leq 85$ & Baik & $\mathrm{B}$ \\
\hline $86 \geq \mathrm{KP} \leq 100$ & Sangat Baik & SB \\
\hline \multicolumn{3}{|c}{ (Riduwan, 2013: 20) } \\
\hline
\end{tabular}

Analisis data ketuntasan hasil belajar siswa yakni hasil posttest untuk mengetahui ketuntasan sesuai KKM (kriteria ketuntasan minimal), dilakukan penghitungan dengan rumus sebagai berikut:

Nilai $=$ jumlah skor perolehan $\times 100$ jumlah skor maksimal

Data posttest dianalisis menggunakan independent sample t-test dengan SPSS 25.00. Sebelumnya dilakukan uji analisis prasyarat yaitu uji normalitas dan uji homogenitas.

Analisis data hasil angket respon siswa untuk mengetahui tanggapan siswa terhadap 
pembelajaran IPA menggunakan model pembelajaran Discovery Learning pada materi Pemanasan Global. Setiap pernyataan siswa pada angket respon siswa diubah menjadi skor, apabila menilai "Ya" skornya 1 dan "Tidak" skornya 0 (Sugiyono, 2015: 139). Data hasil respon siswa terhadap pembelajaran menggunakan model pembelajaran Discovery Learning dianalisis menggunakan rumus sebagai berikut:

Respon positif (\%)

$=$ jumlah respon positif tiap aspek $\times 100$ jumlah maksimal jawaban positif

Data yang diperoleh kemudian dikategorikan beradasarkan pedoman sebagai berikut:

Tabel 2. Kriteria Respon Siswa

\begin{tabular}{|c|c|c|}
\hline $\begin{array}{c}\text { Respon Sisiwa } \\
(\%)\end{array}$ & Kriteria & Simbol \\
\hline $46 \leq \mathrm{RP} \leq 55$ & Sangat Kurang & SK \\
\hline $56 \geq \mathrm{RP} \leq 65$ & Kurang & $\mathrm{K}$ \\
\hline $66 \geq \mathrm{RP} \leq 75$ & Cukup & $\mathrm{C}$ \\
\hline $76 \geq \mathrm{RP} \leq 85$ & Baik & $\mathrm{B}$ \\
\hline $86 \geq \mathrm{RP} \leq 100$ & Sangat Baik & SB \\
\hline \multicolumn{3}{|c|}{ (Riduwan, 2013: 20) } \\
\hline
\end{tabular}

\section{HASIL DAN PEMBAHASAN}

Penelitian ini dilaksanakan di SMP Darul Ulum 5 Jombang tahun ajaran 2017/2018 pada siswa kelas VII semester genap di bulan Mei 2018. Penelitian ini merupakan penelitian true experimental design. Tujuan penelitian ini adalah untuk mengkaji pengaruh gender terhadap hasil belajar siswa menggunakan model pembelajaran discovery learning. Materi yang digunakan dalam penelitian ini adalah Pemanasan Global.

Tabel 3. Ketuntasan Hasil Belajar Siswa Kelas Putri Berdasarkan Posttest

\begin{tabular}{|c|c|c|}
\hline $\begin{array}{c}\text { Jumlah } \\
\text { Siswa }\end{array}$ & Nilai & Kriteria \\
\hline 4 & 100 & Tuntas \\
\hline 6 & 90 & Tuntas \\
\hline 10 & 80 & Tuntas \\
\hline 1 & 70 & Tuntas \\
\hline 1 & 60 & Tidak Tuntas \\
\hline 3 & 30 & Tidak Tuntas \\
\hline Rata-rata & $\mathbf{7 8 , 4}$ & Tuntas \\
\hline
\end{tabular}

Berdasarkan Tabel 3 terlihat bahwa hasil posttest dari 25 siswa kelas putri terdapat 4 siswa tidak tuntas dan 21 siswa tuntas. Secara keseluruhan rata-rata nilai yang diperoleh siswa setelah pembelajaran menggunakan model pembelajaran discovery learning pada materi Pemanasan Global adalah 78,4 dengan kriteria tuntas.

Tabel 4. Ketuntasan Hasil Belajar Siswa Kelas Putra Berdasarkan Posttest

\begin{tabular}{|c|c|c|}
\hline $\begin{array}{c}\text { Jumlah } \\
\text { Siswa }\end{array}$ & Nilai & Kriteria \\
\hline 2 & 90 & Tuntas \\
\hline 4 & 80 & Tuntas \\
\hline 4 & 70 & Tuntas \\
\hline 8 & 60 & Tidak Tuntas \\
\hline 5 & 50 & Tidak Tuntas \\
\hline 3 & 40 & Tidak Tuntas \\
\hline 2 & 30 & Tidak Tuntas \\
\hline 2 & 20 & Tidak Tuntas \\
\hline Rata-rata & $\mathbf{5 8}$ & Tidak Tuntas \\
\hline
\end{tabular}

Tabel 4 menunjukkan bahwa rata-rata hasil belajar siswa kelas putra adalah 58, dalam kriteria tidak tuntas. Berdasarkan Tabel 4.8 dari 30 siswa yang mengerjakan posttest terdapat 10 siswa yang nilainya mencapai ketuntasan dan terdapat 20 siswa yang nilainya belum mencapai ketuntasan.

Pada kategori gender dianalisis dengan menggunakan uji-t untuk mengetahui perbedaan hasil belajar mata pelajaran IPA antara siswa putrid an siswa putra. Diketahui bahwa terdapat perbedaan hasil belajar antara siswa putri dan siswa putra dengan nilai mean siswa putri 78,40 dan untuk siswa putra 58,00. Berdasarkan nilai tersebut dapat ditarik pemahaman bahwa hasil belajar mata pelajaran IPA siswa putri lebih tinggi dari pada siswa putra.

Dari data posttest kemudian dianalisis untuk mendapatkan kesimpulan hasil penelitian. Sebelum dilakukan uji hipotesis terlebih dahulu dilakukan uji analisis prasyarat yaitu uji normalitas dan uji homogenitas. Dari perhitungan uji normalitas dengan menggunakan Kolmogorov-Smirnov ${ }^{a}$ pada program SPSS 25.00 dengan sig. $>0,05$. Hasil uji normalitas kelas putri dan kelas putra dapat dilihat pada Tabel 5. 
Tabel 5. Hasil Uji Normalitas

\begin{tabular}{|c|c|c|}
\hline Uji Normalita & Nilai Sig & Kesimpulan \\
\hline Kelas Putri & 0,000 & Tidak Normal \\
\hline Kelas Putra & 0,127 & Normal \\
\hline
\end{tabular}

Uji Homogenitas dilakukan dengan menggunakan levene statistic pada program SPSS 25.00 dengan sig. > 0,05. Hasil uji homogenitas ditunjukkan oleh Tabel 6.

Tabel 6. Hasil Uji Homogenitas

\begin{tabular}{|c|c|c|}
\hline Kelas & Nilai Sig. & Kesimpulan \\
\hline Putri-Putra & 0,06 & Homogen \\
\hline
\end{tabular}

Setelah data hasil belajar (posttest) dilanjutkan dengan uji hipotesis menggunakan independent sample t-test. Adapun rumusan hipotesis pada penelitian ini adalah sebagai berikut.

$\mathrm{H}_{0}$ : Tidak ada pengaruh yang positif dan signifikan perbedaan gender terhadap hasil belajar IPA pada siswa kelas VII SMP Darul Ulum 5 Jombang.

Ha: Ada pengaruh yang positif dan signifikan perbedaan gender terhadap hasil belajar IPA pada siswa kelas VII SMP Darul Ulum 5 Jombang. Hasil uji-t terhadap nilai posttest pada kelas putri dan kelas putra ditunjukkan pada Tabel 7 berikut ini.

Tabel 7. Hasil Uji-t

\begin{tabular}{|c|c|}
\hline Kelas & Sig. (2-tailed) \\
\hline Putri-Putra & 0,000 \\
\hline
\end{tabular}

Dari Tabel 7 dapat diketahui nilai signifikansi sebesar $0,000<0,05$ yang menunjukkan bahwa $\mathrm{Ha}$ diterima dan $\mathrm{H}_{0}$ ditolak. Dengan demikian dapat disimpulkan bahwa terdapat pengaruh gender terhadap hasil belajar siswa menggunakan model pembelajaran Discovery Learning pada materi Pemanasan Global kelas VII di SMP Darul Ulum 5 Jombang.

Angket respon siswa berisi pernyataanpernyataan untuk mengetahui penilaian siswa setelah menggunakan model pembelajaran discovery learning pada saat kegiatan pembelajaran. Adapun respon siswa kelas putri ditunjukkan pada Tabel 8 sedangkan angket respon siswa kelas putra ditunjukkan pada Tabel 9.

Tabel 8. Hasil Angket Respon Siswa Kelas Putri

\begin{tabular}{|c|c|c|c|}
\hline \multirow{2}{*}{ Pernyataan } & \multicolumn{2}{|c|}{ Respon Ya } & \multirow{2}{*}{ Kriteria } \\
\hline & $\sum$ & $\%$ & \\
\hline Saya aktif dalam pembelajaran IPA ini. & 24 & 96 & Sangat Baik \\
\hline $\begin{array}{l}\text { Pembelajaran IPA ini menyenangkan dengan adanya kegiatan } \\
\text { praktikum. }\end{array}$ & 23 & 92 & Sangat Baik \\
\hline $\begin{array}{l}\text { Pembelajaran IPA ini membuat saya lebih berani bertanya dan } \\
\text { mengemukakan pendapat, sehingga bisa melatih berkomunikasi } \\
\text { dengan baik. }\end{array}$ & 22 & 88 & Sangat Baik \\
\hline $\begin{array}{l}\text { Dengan kegiatan berkelompok dalam tim, mendorong saya } \\
\text { menemukan ide-ide baru. }\end{array}$ & 25 & 100 & Sangat Baik \\
\hline Pembelajaran seperti ini memudahkan saya untuk memahami materi. & 21 & 84 & Baik \\
\hline $\begin{array}{l}\text { Saya lebih percaya diri dalam pembelajaran IPA ini, karena terlibat } \\
\text { langsung di setiap kegiatan pembelajaran. }\end{array}$ & 25 & 100 & Sangat Baik \\
\hline $\begin{array}{l}\text { Pembelajaran IPA ini dapat meningkatkan rasa ingin tahu saya } \\
\text { terhadap pelajaran IPA. }\end{array}$ & 22 & 88 & Sangat Baik \\
\hline $\begin{array}{l}\text { Pembelajaran IPA ini dapat membuat saya lebih mudah dalam } \\
\text { mengingat materi pelajaran IPA. }\end{array}$ & 23 & 92 & Sangat Baik \\
\hline $\begin{array}{l}\text { Dengan model pembelajaran ini, saya menjadi terlatih menyelesaikan } \\
\text { masalah yang berkaitan dengan kehidupan sehari-hari. }\end{array}$ & 21 & 84 & Baik \\
\hline $\begin{array}{l}\text { Saya lebih bersemangat untuk belajar IPA dengan pembelajaran ini } \\
\text { dibandingkan pembelajaran biasa. }\end{array}$ & 17 & 68 & Cukup \\
\hline Rata-rata & 22,3 & 89,2 & Sangat Baik \\
\hline
\end{tabular}


Berdasarkan Tabel 8 dapat diketahui bahwa terdapat 7 pernyataan yang mendapat kriteria sangat baik. Ada 2 pernyataan mendapat respon dengan kriteria baik, sedangkan pernyataan nomor 10 mendapat respon positif dengan kriteria cukup. Adapun rata-rata hasil respon siswa adalah
89,2\% dengan kriteria sangat baik. Hal ini menunjukkan bahwa pembelajaran IPA menggunakan model pembelajaran discovery learning pada materi Pemanasan Global, mata pelajaran IPA kelas VII putri di SMP Darul Ulum 5 Jombang mendapat respon positif sangat baik.

Tabel 9. Hasil Angket Respon Siswa Kelas Putra

\begin{tabular}{|c|c|c|c|}
\hline \multirow{2}{*}{ Pernyataan } & \multicolumn{2}{|c|}{ Respon Ya } & \multirow{2}{*}{ Kriteria } \\
\hline & $\sum$ & $\%$ & \\
\hline Saya aktif dalam pembelajaran IPA ini. & 30 & 100 & Sangat Baik \\
\hline $\begin{array}{l}\text { Pembelajaran IPA ini menyenangkan dengan adanya kegiatan } \\
\text { praktikum. }\end{array}$ & 29 & 97 & Sangat Baik \\
\hline $\begin{array}{l}\text { Pembelajaran IPA ini membuat saya lebih berani bertanya dan } \\
\text { mengemukakan pendapat, sehingga bisa melatih berkomunikasi } \\
\text { dengan baik. }\end{array}$ & 26 & 87 & Sangat Baik \\
\hline $\begin{array}{l}\text { Dengan kegiatan berkelompok dalam tim, mendorong saya } \\
\text { menemukan ide-ide baru. }\end{array}$ & 28 & 93 & Sangat Baik \\
\hline Pembelajaran seperti ini memudahkan saya untuk memahami materi. & 30 & 100 & Sangat Baik \\
\hline $\begin{array}{l}\text { Saya lebih percaya diri dalam pembelajaran IPA ini, karena terlibat } \\
\text { langsung di setiap kegiatan pembelajaran. }\end{array}$ & 24 & 80 & Baik \\
\hline $\begin{array}{l}\text { Pembelajaran IPA ini dapat meningkatkan rasa ingin tahu saya } \\
\text { terhadap pelajaran IPA. }\end{array}$ & 27 & 90 & Sangat Baik \\
\hline $\begin{array}{l}\text { Pembelajaran IPA ini dapat membuat saya lebih mudah dalam } \\
\text { mengingat materi pelajaran IPA. }\end{array}$ & 27 & 90 & Sangat Baik \\
\hline $\begin{array}{l}\text { Dengan model pembelajaran ini, saya menjadi terlatih menyelesaikan } \\
\text { masalah yang berkaitan dengan kehidupan sehari-hari. }\end{array}$ & 26 & 87 & Sangat Baik \\
\hline $\begin{array}{l}\text { Saya lebih bersemangat untuk belajar IPA dengan pembelajaran ini } \\
\text { dibandingkan pembelajaran biasa. }\end{array}$ & 27 & 90 & Sangat Baik \\
\hline Rata-rata & 27,4 & 91,4 & Sangat Baik \\
\hline
\end{tabular}

Berdasarkan Tabel 9 dapat diketahui bahwa rata-rata respon adalah $91,4 \%$ dengan kriteria sangat baik. Hal ini menunjukkan bahwa pembelajaran IPA menggunakan model pembelajaran discovery learning pada materi Pemanasan Global, mata pelajaran IPA kelas VII putra di SMP Darul
Ulum 5 Jombang mendapat respon positif sangat baik.

Rekapitulasi komentar dan saran dari siswa kelas putri terhadap pembelajaran IPA menggunakan model pembelajaran discovery learning disajikan pada Tabel 10.

Tabel 10. Rekapitulasi Komentar dan Saran Siswa Kelas Putri

\begin{tabular}{|l|}
\hline \multicolumn{1}{|c|}{ Komentar dan Saran } \\
\hline $\begin{array}{l}\text { Pelajaran IPA ini saya sangat menyukainya, karena dapat membuat saya lebih berani bertanya dan } \\
\text { mengemukakan pendapat sehingga bisa melatih berkomunikasi dengan baik. }\end{array}$ \\
\hline Pembelajaran IPA ini dapat membuat saya lebih mudah dalam mengingat materi IPA. \\
\hline Dalam pelajaran IPA, saya jauh lebih mengetahui tentang hal-hal yang sulit dan bersemangat. \\
\hline Pelajaran IPA sangat menyenangkan dan membuat saya paham dengan pelajaran IPA. \\
\hline Pelajaran IPA ini meningkatkan rasa ingin tahu saya. \\
\hline $\begin{array}{l}\text { Saya jujur tidak menyukai IPA karena biologi dan hitungan. Tapi dengan pembelajaran IPA seperti } \\
\text { ini saya mulai menyukai IPA. }\end{array}$ \\
\hline $\begin{array}{l}\text { Saya senang sekali dengan pembelajaran IPA seperti ini karena menuntun saya bersemangat } \\
\text { belajar IPA. Saya ingin dibimbing seperti ini. }\end{array}$ \\
\hline
\end{tabular}


Berdasarkan Tabel 10, siswa kelas VII A (kelas putri) memberikan komentar dan saran yang sangat positif terhadap pelakasanaan pembelajaran menggunakan model pembelajaran discovery learning. Berdasarkan komentar dan saran, siswa lebih senang, suka, lebih berani bertanya dan mengemukakan pendapat, lebih mudah dalam mengingat materi IPA serta bersemangat saat pembelajaran IPA menggunakan model pembelajaran discovery learning pada materi Pemanasan Global. Selain itu, model pembelajaran tersebut dapat meningkatkan rasa ingin tahu siswa pada pembelajaran IPA.

Adapun rekapitulasi komentar dan saran dari siswa kelas putra terhadap pembelajaran IPA menggunakan model pembelajaran discovery learning dapat dilihat pada Tabel 11 berikut ini.

Tabel 11. Rekapitulasi Komentar dan Saran Siswa Kelas Putra

\begin{tabular}{|l|}
\hline \multicolumn{1}{|c|}{ Komentar dan Saran } \\
\hline Pembelajaran IPA seperti ini menjadikan saya lebih bersemangat dari pada pembelajaran biasa. \\
\hline Menurut saya, pelajaran IPA itu tidak selalu serius, selalu ada senangnya dan untuk melatih kreatif. \\
\hline Pembelajaran IPA membuat pengalaman terbaik saya yang lebih menarik, karena kita bisa tahu \\
keadaan bumi yang sekarang. \\
\hline Pelajarannya lebih seru dan saya lebih bisa tahu dan lebih berani bertanya dengan pembelajaran \\
IPA seperti ini. \\
\hline $\begin{array}{l}\text { Saya senang karena langsung praktikum dalam pembelajaran ini dan saya lebih cepat paham } \\
\text { dalam materi ini. }\end{array}$ \\
\hline
\end{tabular}

Berdasarkan Tabel 11, siswa kelas putra memberikan komentar dan saran yang sangat positif terhadap pelakasanaan pembelajaran menggunakan model pembelajaran discovery learning. Berdasarkan komentar dan saran, siswa suka, senang, lebih berani bertanya, lebih seru dan bersemangat saat pembelajaran IPA menggunakan model pembelajaran discovery learning pada materi Pemanasan Global. Selain itu, model pembelajaran tersebut dapat meningkatkan rasa ingin tahu siswa pada pembelajaran IPA.

\section{SIMPULAN}

Berdasarkan hasil penelitian yang dilaksanakan mengenai pembelajaran IPA di kelas gender terhadap hasil belajar siswa kelas VII SMP darul Ulum 5 Jombang menggunakan model pembelajaran discovery learning, dapat disimpulkan bahwa: (1) Hasil belajar siswa kelas putri menggunakan model pembelajaran discovery learning pada materi Pemanasan Global. Berdasarkan hasil posttest yang dilakukan ada 4 siswa yang mendapatkan predikat tidak tuntas dan 21 siswa mendapatkan predikat tuntas. (2) Hasil belajar siswa kelas putra menggunakan model pembelajaran discovery learning pada materi Pemanasan Global. Berdasarkan hasil posttest yang dilakukan ada 20 siswa yang mendapatkan predikat tidak tuntas dan 10 siswa mendapatkan predikat tuntas. (3) Gender sangat berpengaruh terhadap hasil belajar siswa kelas VII SMP Darul Ulum 5 Jombang. Berdasarkan uji normalitas data posttest siswa kelas putri nilai sig. $0,000<$ 0,05 berarti nilai data tidak berdistribusi normal, sedangkan kelas putra menunjukkan nilai sig. $0,127>0,05$, sehingga nilai data distribusi normal. Adapun uji homogenitas data posttest kelas putri dan putra menunjukkan nilai sig. 0,06>0,05 maka data yang diperoleh dari hasil penelitian ini memiliki varian homogen. Hasil uji-t posttest kelas putri dan kelas putra diperoleh nilai sig. sebesar $0,000<0,05$ yang menunjukkan bahwa $\mathrm{Ha}$ diterima dan $\mathrm{H}_{0}$ ditolak, sehingga dapat disimpulkan bahwa terdapat pengaruh gender terhadap hasil belajar siswa kelas VII SMP Darul Ulum 5 Jombang mata pelajaran IPA materi Pemanasan Global menggunakan model pembelajaran Discovery Learning. (4) Pembelajaran menggunakan model pembelajaran discovery learning pada materi pemanasan global pertemuan pertama siswa kelas VII A (kelas putri) terlaksana dengan persentase rata-rata keterlaksanaan adalah 98,5\% dengan kriteria sangat baik, dan pada kelas VII B (kelas putra) terlaksana 
dengan persentase rata-rata keterlaksanaan adalah $97 \%$ dengan kriteria sangat baik, sedangkan pada pertemuan kedua kelas putri dan kelas putra dengan metode diskusipresentasi terlaksana dengan sangat baik, persentase nilai rata-rata keterlaksanaan pembelajaran yaitu $100 \%$. Pada pertemuan ketiga materi pemanasan global pada siswa kelas putri dan kelas putra dengan menggunakan model pembelajaran discovery learning terlaksana dengan sangat baik, persentase nilai rata-rata keterlaksanaan pembelajaran yaitu $100 \%$. (5) Respon siswa terhadap penggunaan model pembelajaran Discovery Learning pada materi Pemanasan Global menunjukkan respon positif dengan hasil rata-rata $89,2 \%$ oleh kelas putri dengan kriteria sangat baik dan hasil rata-rata 91,4\% oleh kelas putra termasuk dalam kriteria sangat baik.

Berdasarkan hasil penelitian dalam penelitian ini, ada beberapa saran penulis terkait penelitian ini yaitu, (1) Guru direkomendasikan untuk menggunakan

\section{DAFTAR PUSTAKA}

Akromah, Siti. 2017. Pengaruh Model Pembelajaran Discovery Learning terhadap Kemampuan Berpikir Kritis Siswa Mata Pelajaran IPA Materi Sistem Tata Surya Kelas VIII di MTs Babussalam Kalibening Mojoagung. Skripsi tidak diterbitkan. Jombang. Universitas Hasyim Asy'ari Tebuireng.

Kurniasih, Imah dan Berlin Sani. 2016. Revisi Kurikulum 2013. Implementasi Konsep dan Penerapan. Jakarta. Kata Pena.

Munandar, Utami. 2004. Mengembangkan Bakat dan Kreatif Anak Sekolah. Jakarta. Gramedia.

Riduwan dan Akdon. 2013. Rumus dan Data dalam Analisis Statistika. Bandung. Alfabeta.

Sugihartono, dkk. 2012. Psikologi Pendidikan. Yogyakarta. UNY Press. model pembelajaran Discovery Learning pada materi Pemanasan Global karena berdasarkan hasil pengamatan, keterlaksanaan pembelajaran yang dilakukan saat pembelajaran sangat baik dan respon siswa positif terhadap pembelajaran tersebut. (2) Guru disarankan untuk lebih memperhatikan sifat dari siswa laki-laki dan perempuan, sehingga dapat menentukan model pembelajaran yang sesuai dengan karakteristik gender siswa tersebut. Agar hasil belajar siswa dapat mencapai kriteria ketuntasan. (3) Untuk peneliti selanjutnya, perlu ditambahkan data awal kemampuan pengetahuan (kognitif) siswa kelas gender putra dan putri dengan memberikan pretest terlebih dahulu. (4) Untuk peneliti selanjutnya, perlu ditambahkan rubrik penskoran (kadar nilai) yang digunakan sebagai acuan observer dalam melakukan observasi keterlaksanaan pembelajaran pada model pembelajaran yang digunakan. (5) Guru dan peneliti selanjutnya disarankan untuk memperhatikan waktu yang tersedia agar proses pembelajaran lebih efektif.

Sugiyono. 2015. Metode Penelitian Pendidikan Pendekatan Kuantitatif, Kualitatif, dan $R \& D$. Bandung. CV. Alfabeta.

Sulistiana, Sriyono, Nurhidayati. 2013. "Pengaruh Gender, Gaya Belajar, dan Reinforcement Guru terhadap Prestasi Belajar Fisika Siswa Kelas XI SMA Negeri se-Kabupaten Purworejo Tahun Pelajaran 2012/2013". Jurnal Edukasi Universitas Muhammadiyah Purworejo. (Online) Radiasi Vol.3. No.2, (http://id.potalgaruda.org/index.php?ref $=$ browse $\& \bmod =$ viewarticle $=97650$, diunduh 7 Januari 2018)

Wisudawati, Asih Widi dan Eka Sulistyowati. 2015. Metodologi Pembelajaran IPA. Jakarta. PT. Bumi Aksara.

Wisuda Zahroh, Fatmawati. 2012. Pengaruh Gender Terhadap Motivasi Memilih Sekolah Dan Prestasi Belajar. Skripsi tidak diterbitkan. 